\title{
MEMORIES AND STORIES OF RETURNING HOME IN KHALED HOSSEINI'S NOVELS THE KITE RUNNER, AND THE MOUNTAINS ECHOED, A THOUSAND SPLENDID \\ SUNS
}

\author{
Elena Spirovska, South East European University, Republic of \\ Macedonia, e.spirovska@seeu.edu.mk
}

DOI: $10.31902 /$ fII.31.2020.3

UDK 821.111(73).09-31

\begin{abstract}
The aim of this paper is to analyze the acts of returning home, thinking about home and the significance of home and returning home in Khaled Hosseini's novels The Kite Runner, A Thousand Splendid Suns, and in the novel And the Mountains Echoed. As an American writer of Afghan origin, who left his home country as a child and moved to USA, Khaled Hosseini addresses the concepts of leaving home, immigration, and returning home in all of his published novels. In 2003, Khaled Hosseini published his first novel The Kite Runner. This story depicts the friendship between two Afghan boys, whose relationship is broken by the Afghan civil war and the violence before and in the aftermath of the war. In this novel, returning home is an act of redemption on behalf of Amir, for the betrayal of his best friend Hassan. Hosseini's second novel, A Thousand Splendid Suns, describes the relationship between two women and their lives under the Taliban regime. Mariam's and Laila's life stories are intertwined the moment Laila, forced by the circumstances in Kabul during the civil war and the loss of her parents and her home, accepts Rasheed's marriage proposal, becoming his second wife. The strained relationship between her and Mariam develops into close friendship, which ends the day Mariam kills Rasheed to protect Laila. Laila returns to Afghanistan and visits Mariam's home. For her, this is an act of paying respect, of visiting a place where she can sense Mariam's soul and her presence. And the Mountains Echoed presents the life stories of a number of characters, mutually connected in different ways. One of the sibling relationships described is the relationship between Pari and Abdullah who are separated as children. Pari, who leaves her home and is adopted, always feels the strange sensation of being homesick and missing somebody or something in her life. For Pari, who plans to travel to Afghanistan in attempt to find the answers to her questions, the act of returning home is exploring her own personality and heritage.
\end{abstract}

Key words: Home, returning, home, redemption, reunited. 


\section{Introduction}

The aim of this paper is to analyze the acts of returning home, thinking about home, and the significance of home and returning home in Khaled Hosseini's novels The Kite Runner, A Thousand Splendid Suns, and in the novel And the Mountains Echoed. As an American writer of Afghan origin, who left his home country as a child and moved to USA, Khaled Hosseini addresses the concept of leaving home, immigration and returning home in all of his published novels.

Khaled Hosseini was born in Kabul, Afghanistan on March 4th, 1965. As a son of an Afghan diplomat, he lived with his family in Paris. During this period, Afghanistan was occupied by Soviet military forces. In order to avoid returning to Kabul, Hosseini's family sought political asylum in the United States. After they were granted the asylum, they moved to San Jose, California.

In his interview for the Radio Free Europe, in 2012, Hosseini described Kabul and his home in the following way:

And, you know, Afghanistan was a country at peace with itself, with its neighbors. Kabul was a growing, thriving, cosmopolitan city. So it was a very, very different picture of Afghanistan than the one you would think of today if somebody said the word Afghanistan. So I feel very fortunate to have lived through the final few peaceful years of recent Afghan history.

The first years after the relocation to United States were difficult for Hosseini's family and himself. His parents were uprooted from their home, their financial security has disappeared and they had to start again their lives in a completely different environment, culturally and financially, from the one they were used to. However, Hosseini was very much aware of the other side of the coin: a lot of Afghans were forced to leave their homes and to live in the immigrant camps in Pakistan or Iran. Through the characters depicted in his novels, Hosseini presents his own personal dilemmas, struggles, and ambiguous acceptance of the new home. As an author who writes about the diaspora (in his case Afghan and Islamic diaspora), Hosseini defines in his novels the meaning of "homeland" and home. Blumenthal states the following regarding the term of homeland in Hosseini's novels:

These diasporic writers document more than just the physical journey from one geography to another, however. They 
traverse national boundaries, but also ideological boundaries. Their texts uncover new ideological homelands, or intellectual and moral regions in which they locate evolving political, theological and social beliefs. (Blumenthal, 251)

Perhaps one of the most prominent aspects of Hosseini's novels, apart from defining homeland and home, are the stories of the characters' returning home and the meaning of returning home for them. For Amir, the main character in the novel The Kite Runner, returning home is redemption and an attempt to make peace with himself and his guilt over his betrayal. For Laila, the character from his novel A Thousand Splendid Suns, returning to Mariam's home is an act of remembering and paying respect to Mariam, almost an act of brining Mariam back to life. For Pari, a character in Hosseini's novel And the Mountains Echoed, returning home means more than a visit to a long-forgotten place. For her, returning home is a quest for identity and a long-forgotten connection with her brother.

\section{The Kite Runner - Returning Home as Redemption}

In 2003, Khaled Hosseini published his first novel The Kite Runner. The novel portrays the characters of Amir and Hassan and the friendship between these two Afghan boys whose relationship is broken by the Afghan civil war and the violence before and in the aftermath of the war. In this novel, returning home is an act of redemption on behalf of Amir, for the betrayal of his best friend Hassan.

Answering what specific aspects of the Afghan diaspora are represented in Amir's character, in an interview for the Afghan Magazine in 2004, Hosseini stated the following about Amir's character:

Nostalgia and longing for the homeland. The preservation of culture and language: Amir marries an Afghan woman and stays an active member of the Afghan community in the East Bay; the hard-working immigrant value system; and some sense of survivor's guilt, which I think many of us, particularly in sunny California, have felt at one time or another. (Hosseini 2004)

Hosseini's words reveal, at least partially, the autobiographical element in his novel The Kite Runner, since Amir leaves Afghanistan 
under the same circumstances as Khaled Hosseini and faces similar difficulties. Amir, a child of a wealthy Afghani businessman and a highly educated woman who dies giving birth to him, grows up in Kabul, almost inseparable of his childhood companion, Hassan. The relationship between the two is very complex. Their ethnic background is different. While Amir is a member of the privileged and respected Pashtu group, Hassan is an ethnic Hazara, considered and treated as a second-class citizen in the Afghan society. Hassan, a child of the household servant and a woman who left the family after giving birth to him, does not hide his admiration and unwavering loyalty for Amir. Amir describes their relationship as follows:

But in none of these stories did Baba ever refer to Ali as his friend. The curious thing was, I never thought of Hassan and me as friends either. Not in the usual sense anyhow. [...] Because history isn't easy to overcome. Neither is religion. (Hosseini 27)

Although Hassan saves Amir from a violent attack and confronts their violent peer Assef and his retribution, Amir still feels the disparity between him and Hassan. Even in the aftermath of the attack on Hassan, after he is assaulted by Assef, Amir still doesn't overcome his sense of superiority over Hassan. On the contrary, Hassan's persistent admiration and loyalty annoys him, in addition to his jealousy over his father's love towards him and Hassan equally. It is obvious to the reader that he is tormenting Hassan out of his own sense of guilt and remorse, for not helping his companion when he needed him the most. These feelings intensify when he received an expensive birthday gift from Hassan and his father Ali. Overwhelmed with guilt, Amir decides to drive both Hassan and Ali out of his household, by wrongfully accusing his friend and his father of stealing. A part of him feels relieved, hoping that once he stops seeing Hassan on daily basis, he will forget everything about him, about the guilt and about the attack. Of course, this is not the case. Amir notices that he cannot forget the past: "It's wrong what they say about the past, I've learned, about how you can bury it. Because the past claws its way out" (Hosseini 1).

Later, after the Soviet occupation of Afghanistan and after he immigrated to USA, Amir finds out what he secretly suspected a long time ago: that Hassan is his biological brother, a result of his father's love affair with a household servant. At that moment, Amir doesn't have a choice. 
Returning home to Afghanistan is the only option, the only course of action for him. It is the only way for Amir to redeem himself. Hassan is dead, killed by the Taliban forces in the aftermath of the civil war in Afghanistan. The only way for Amir to appease his conscience and to relieve himself of his sense of guilt is to travel to Afghanistan, to risk his safety of living in USA, to risk his life and to try to save Hassan's son Sohrab. Describing Amir's decision and motives, Saraswat understands that "Amir finally became the man who stood up for himself and his sins" (172). However, there is no easy way to save Sohrab and to take him out of Afghanistan and later Pakistan. Broken and traumatized by Amir's unfulfilled promises, Sohrab attempts suicide. Following his suicide attempt and months after he is transferred and lives in USA, Sohrab is unable to speak and to communicate. His first reaction, the first sign that Amir is redeemed and that his returning home brings him at least some peace of mind, is his smile after Amir runs his kite during the Afghan immigrants gathering in Fremont. Amir describes Sohrab's reaction:

It was only a smile, nothing more. It didn't make everything all right. It didn't make anything all right. Only a smile. A tiny thing. A leaf in the woods, shaking in the wake of a startled bird's flight. But I'll take it. With open arms. Because when spring comes, it melts the snow one flake at a time, and maybe I just witnessed the first flake melting. (Hosseini 401)

\section{A Thousand Splendid Suns - Returning Home as Remembering}

Hosseini's second novel, A Thousand Splendid Suns, describes the relationship between two women and their lives under the Taliban regime. Mariam's and Laila's life stories are intertwined the moment Laila, forced by the circumstances in Kabul during the civil war and the loss of her parents and her home, accepts Rasheed's marriage proposal, becoming his second wife.

Laila's motive for accepting Rasheed's proposal stems from several reasons. Her own home is destroyed by bombing and Laila's parents are killed. Years prior to the bombing which killed her mother and father, Laila desperately tries to maintain her home and to help her father. Her mother, desperate and depressive after her sons are killed in battle with Soviet soldiers, is unable to function and communicate with her husband and her daughter. Laila doesn't really have a home even before her home is physically destroyed. In her 
mind, her brothers are distant, almost saintly figures who have never really existed. Her mother is a weak, fragile woman who is almost always in bed, hoping only for Soviet's defeat and revenge for her sons' death. However, Laila's best friend, Tariq, is alive. He is Laila's comfort and support, her protector and, eventually, her lover. Immediately after the bombing, Laila discovers that she is pregnant. There is only one way to protect herself and her unborn baby, and that is to remain in Rasheed's home as his wife.

The strained relationship between her and Mariam slowly develops into close friendship. Mariam is more than a friend to Laila. Laila sees her as a mother that she has never had, since her own mother did not show awareness of Laila after her sons' death. Mariam adores Aziza, Laila's daughter, being aware that Aziza is not Rasheed's daughter, but harami, an illegitimate child, just like Mariam. This bond between them ends the day Mariam kills Rasheed to protect Laila. In the Taliban regime, this means only one thing: that Mariam and, quite possibly, Laila are to be sentenced to death and executed by Taliban officials. But Mariam's sacrifice doesn't stop there. She orders Laila to leave with her children, Aziza and Zalmai, and she turns herself in, knowing very well that she won't be spared the death sentence.

After Mariam's execution, Laila returns to Afghanistan and visits Mariam's home. In Laila's case, Kabul does not represent Mariam's home. Mariam never experienced happiness or the feeling that she is at home in Rashid's house. Instead, Laila visits Mariam's childhood home in Herat, a city in northern Afghanistan, where Mariam is born. For Laila, this is an act of paying respect, of visiting a place where she can sense Mariam's soul and her presence.

When Laila heads towards Herat, the town where Mariam grew up, she feels that it is easier for her to evoke Mariam's face and her voice. After years of living outside Afghanistan, her memory of Mariam is vague. Still, at the moment she enters Mariam's dilapidated home in a village near Herat, she remembers Mariam.

In Pakistan, it was difficult sometimes to remember the details of Mariam's face. There were times when, like a word on the tip of her tongue, Mariam's face eluded her. But now, here in this place, it is easy to summon Mariam behind the lids of her eyes, the soft radiance of her gaze, the long chin, the coarsened skin of her neck, her tight-lipped smile. (Hosseini 427) 
It is returning to Mariam's home, returning to the only place where Mariam's life gave Mariam a rare chance of happiness, that gives back to Laila the memory of Mariam and the vision of Mariam living in the shack in the mountains surrounding Herat.

Laila watches Mariam glue strands of yarn onto her doll's head. In a few years, this little girl will be a woman who will make small demands on life, who will never burden others, who will never let on that she too has had sorrows, disappointments, dreams that have been ridiculed. A woman who will be like a rock in a riverbed, enduring without complaint, her grace not sullied but shaped by the turbulence that washes over her. (Hosseini 428)

Blumenthal (2012) refers to the illustration of the novel $A$ Thousand Splendid Suns when defining the concept of homeland and home, saying that the illustration on the cover

shows a lone Muslim woman dressed in hijab, looking over what is presumably an Afghani landscape. Hosseini's characters may look, in part, the West for an ideological homeland, but ultimately, Hosseini crafts his novels as generic and paratextual testaments to his characters' inability to locate consistently within a Western or an Afghani homeland. (262)

Similarly, to immigrants to western countries, Laila, while living in Pakistan after she leaves Afghanistan with her children, does not feel at home. Despite the fact that she is happy with Tariq, she still feels that she needs to go home, even though a home does not exist in the real sense of the word. She thinks of Kabul perhaps not so much with nostalgia as with restlessness. The changes in Afghanistan and her desire to witness them and to participate in them are the driving force for Laila. She thinks about her parents when deciding to go back: "There is a part of Laila now that wants to return to Kabul, for Mammy and Babi, for them to see it through her eyes" (415). However, there is Mariam and her death, even now, when Laila wants to return to Kabul, the city where Mariam was executed. Laila asks herself the following question about Mariam:" Did she sacrifice herself so she, Laila, could be a maid in a foreign land?" (415)

Although Leila is aware that her safety and the safety of her children would be a priority for Mariam, she is still aware that Mariam's sacrifice is too big to be traded for complacency with her 
present life, with the comfort and the tranquility of it, although it bears no significance for the changes in her country. Therefore, she decides to go back to Kabul, together with Tariq and her children. Along with her visit to Mariam's home in Herat, this is Laila's second home return. Her return, almost symbolically, coincides with the first rains in Kabul and the end of the draught which plagued Kabul for years, during the first years of rebuilding the devastated city. Although returning home is strange and painful for Laila, due to the fact that a number of warlords are not punished for their crimes, she rejects the feeling of anger and resentment. Because, she is aware that Mariam would not want that. Laila decides to move on with her life, because "in the end, she knows that is all she can do. That and hope" (439).

\section{And the Mountains Echoed - Returning Home and Exploring Heritage and Identity}

The novel And the Mountains Echoed is a compilation of different characters and their personal stories, their own search for identity and personal fulfillment. The intertwined stories of multiple characters present their own personal struggles, connections and emotions. The story about the close bond between the siblings Pari and Abdullah is powerfully depicted and moving at the same time. Their bond is forged of closeness beyond sibling relationship, during life of poverty and struggle, with no mother to care for them. His younger sister Pari is the only person who brings Abdullah happiness. For her, he will do everything; even trade his only pair of shoes to give her a feather for her treasured collection of feathers. However, poverty and harsh living conditions take their toll on the family. When their father leaves their home with Pari and Abdullah across the desert to Kabul, Abdullah is determined to stay with Pari. Neither brother nor sister know what this crucial journey will bring them.

In the novel, there are two homes which form two focal points. One is the poverty-stricken home of Saboor, the father of Abdullah and Pari. After Saboor is widowed, his second wife Parwana moves in. The second home is a beautiful grand house in Kabul, owned by Suleiman Wahdati and his wife Nila is the other one. Pari, the biological daughter of Saboor, is the link between these two homes.

For Pari, who is adopted as a young girl to Suleiman Wahdati's house, the memory of her beloved brother the home she grew up in is very vague and almost nonexistent. She struggles with her own identity and inability to establish a less turbulent relationship between herself and her adoptive mother Nila. Moreover, she is aware that Nila is 
equally confused in this relationship. Nila, a beautiful young poet, uses every possible way to rebel against the established societal norms and her domineering father. She uses her beauty and her body to attract lovers, she uses alcohol and drugs to escape from her depression and pain and she uses her poetry to express her thoughts, all of it completely unacceptable for an Afghan woman from a well-known family. For her, Pari is initially a way to commit and to love another human being and later, a punishment. When Nila leaves her home and her husband in Kabul, never to return, she takes Pari with her to France.

Unaware that she is adopted, but aware of the deep rift between herself and her mother, Pari constantly reexamines their relationship, the lack of physical resemblance, the lack of common interests, the lack of emotional connection. Nila is stunningly beautiful, Pari is ordinary looking and not very attractive. Nila is a poet, Pari is a mathematician. Nila struggles with her responsibilities, Pari is reliable and loyal. Nila is completely emotion driven, Pari is rational.

However, Pari is aware that there is something else, essential to her existence, which eludes her memory and cannot be defined, something which goes beyond her relationship with Nila. Since, as long as she remembers, she has the feeling

that there was in her life the absence of something, or someone, fundamental to her own existence. Sometimes it was vague, like a message sent on a radio dial, remote, warbled. Other times it felt so clear, this absence, so intimately close it made her heart lurch. (Hosseini 205)

Later, in France, many years after Nila's death, Pari receives her uncle Nabi's letter and finds out the truth about her family and her origins. Pari never travels to Afghanistan. In her case, returning home is reuniting with Abdullah, many decades after the day her father takes her to Wahdati's house. She reunites with her brother in the United States, where Abdullah lives with his family. Abdullah, who is elderly at the time of their meeting and Alzheimer-stricken, doesn't remember or recognize Pari. But for Pari, this reunion is the missing piece of the puzzle, the answer to her questions so far. This reunion gives her back her sense of identity, the sense that she belongs somewhere and to someone. 


\section{Conclusion}

The stories about returning home in Khaled Hosseini's novels differ in some aspects. However, they share the common thread: none of the stories depicts returning home as an ordinary act which was happily accepted on behalf of the characters. Amir goes back to Afghanistan reluctantly and with fear. Laila returns to a home which is not hers at all. Pari meets Abdullah anxiously and without any idea what to expect. For all of them, returning home is a necessity, almost an involuntary act driven by a number of underlying motives. For Amir, it is the only way to appease his conscience and to make amends. Returning home for Laila is the only way to pay respect to Mariam and her sacrifice. For Pari, reuniting with Abdullah is the only way to find the missing part of herself, the missing piece of the complicated puzzle of her background. Still, returning home answers most of their questions, clarifiers most of their uncertainties and provides, at least partially, some peace of mind. For all of them, returning home is finding answers, but not necessarily happiness.

\section{Works Cited:}

Blumenthal, Rachel. "Looking for Home in the Islamic Diaspora of Ayaan Hirsi Ali, Azar Nafisi, and Khaled Hosseini." Arab Studies Quarterly 34.4 (2012): 250-265.

Hosseini, Khaled. The Kite Runner. New York: Riverhead Books, 2003. Print.

Hosseini, Khaled. A Thousand Splendid Suns. New York: Riverhead Books, 2007. Print.

Hosseini, Khaled. And The Mountains Echoed. New York: Riverhead Books, 2013. Print.

Hosseini, Khaled. Interview by Farhad Azad. Dialogue with Khaled Hosseini, Afghan Magazine, June, 2004.Web.10 June 2019 https://afghanmagazine.com/post/185415461029/dialoguewith-khaled-hosseini

Saraswat, Niraja. "Theme of Identity and Redemption in Khaled Hosseini's The Kite Runner." International Journal of Interdisciplinary and Multidisciplinary Studies (IJIMS). 1. 5(2014):166-175. Web. 10 June 2019 http://103.55.216.55/index.php/elite/article/view/4253/3916 


\section{СПОМЕНИ И ПРИКАЗНИ ЗА ВРАК์АЊЕ ДОМА ВО РОМАНИТЕ НА КАЛЕД ХОСЕИНИ-ЛЕТАЧ НА ЗМЕЈОВИ, КОГА ПЛАНИНИТЕ ОДЕКНАА И ИЛЈАДА НЕВЕРОЈАТНИ СОНЦА}

Целта на овој труд е да го анализира враќањето дома и размисливањата за домот, како и значењето на домот во романите на Калед Хосеини Летач на змејови, Кога планините одекнаа и Илјада неверојатни сонца.Калед Хоссеини е американски автор од авганистанско потекло, кој ја напуштил својата земја во рана возраст и се преселил со семејтвото во Соединетите Американски Држави. Како таков, тој често се навраќа на поимите на напуштање на домот, имиграција и враќање дома во сите негови објавени дела. Во 2003 година, Калед Хоссеини го објавува својот рв роман, Летач на змејови. Делото го опишува пријателството помеѓу две момчиња од Афганистан, кое е нарушено поради граѓанската војна и насилствата пред, за време на и по војната. Во ова дело, враќањето дома на Амир, е со цел да се искупи, поради неговото предавство на неговиот најдобар пријател Хасан. Второто дело на Хосеини, Илјада неверојатни сонца, го опишува пријателството и животот на две жени под талибанскиот режим. Животите на Маријам и Лејла се испреплетуваат во моментот кога Лејла, го прифаќа предлогот за брак од Рашид и станува негова втора сопруга. Таа е присилена од животните услови во Кабул и загубата на нејзините родители. Од почеток напнатата врска меѓу двете жени прераснува во блиско пријателство, кое што завршува дента кога Маријам го убива Рашид за да ја заштити Лејла и е погубена поради тоа. Лејла се враќа во Афганистан и го посетува домот на Маријам, за да ја изкаже својата почит и да го почуствува духот и присуството на Маријам. Делото Кога планините одекнаа ги претставува животните приказни на повеќе ликови, кои се меѓусебно поврзани на повеќе начини. Една од опишаните врски е врската помеѓу братот и сестрата Абдула и Пари, кои се раздвоени како деца. Пари, која го напушта домот и е посвоена, чувствива дека е носталгична и дека некој или нешто и недостига во нејзиниот живот. За неа, враќањето дома е истражување на самата себеси, нејзиното минато и нејзиното потекло.

Клучни зборови: дома, враќање дома, повторно обединување . 